\title{
The local history of Jewish-Gentile relations
}

\author{
Book REVIEW
}

Omer Bartov, Anatomy of a Genocide: The Life and Death of a Town Called Buczacz

(Simon \& Schuster, 2018), 398 pp., illustrated, with maps and an index

Omer Bartov, who has written extensively on the hardships of the Eastern Middle European Jews, is Professor of European History at Brown University, Rhode Island. The present book, Anatomy of a Genocide, focuses on the south-western Ukrainian town of Buczacz, where Bartov's mother lived for around ten years in her youth, before her Aliya to Palestine in I935. It [the book] is based mainly on previous untapped archival material. A bibliography would have been helpful in assessing the work's relation to previous studies.

Bartov's book seems to combine two styles of writing, which both are common, but not often used simultaneously in mapping out Jewish genocides, namely, long historical perspectives (nowadays often appearing in various histories of this or that shtetl), and an extensive use of local voices (in writing), familiar, for example, from the late-twentieth-century 'writing ethnography' trend.

The book is divided into seven chapters and a conclusion entitled 'Aftermath'. The narrative thread is the continually deteriorating position of the Jews. Chapters I to 3 first summarise the early history from the thirteenth century to the partition of Poland in the late eighteenth

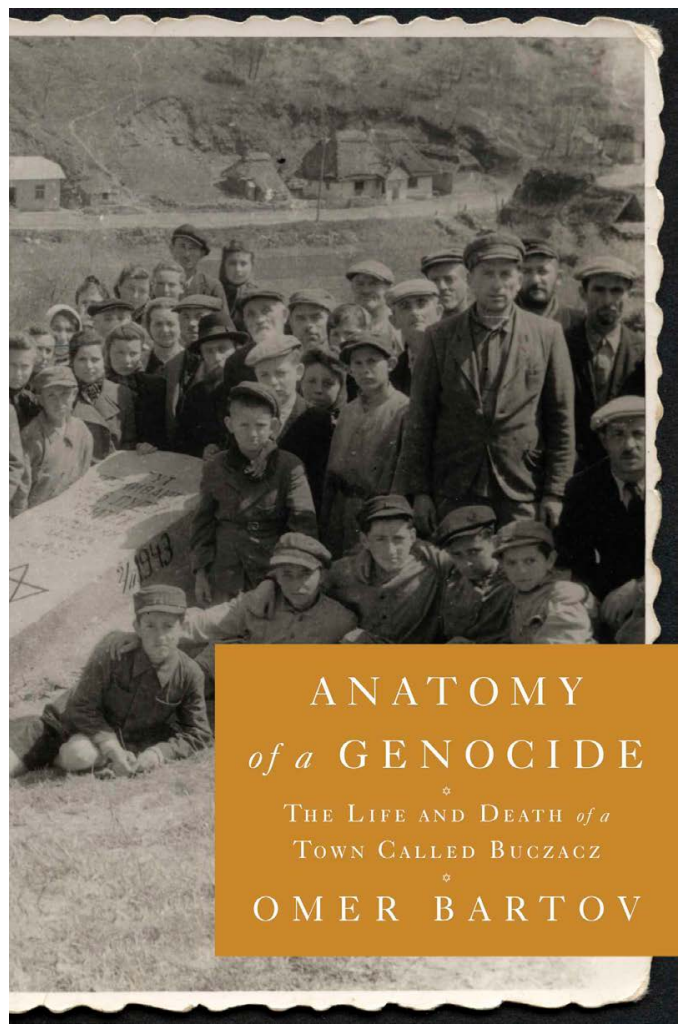

century, when Buczacz was incorporated into the Habsburg Empire, followed by the imperial time' up to the Great War, the wartime (including the civil wars between Ukrainians, Russians and Poles), and the interwar period. The structure is reminiscent of Yehuda Bauer's The Death of the Shtetl (2010). During the whole period, according to Bartov, the Jews were sandwiched between rival nations, first Poles and Ukrainians; 
then, in the Empire, between these and the Germans; during the civil war, between Poles, Ukrainians and Russians of various persuasions; and, finally, again between Poles and Ukrainians.

Most of the time the Jews were regarded as allies by some nations and as enemies by others. However, these relations were shifting and complex, and depended particularly on relations between Poles and Ukrainians. Put simply, the Jews were enemies of those in power and allies of those who were oppressed. Yet, Bartov seems not to be satisfied with this explanation, but quotes writings and testimonies of Jewish, Polish and Ukrainian inhabitants of Buczacz as indicating a permanent antisemitism among, in particular, the Poles (see, for example, quotations from the diary of the Buczacz teacher Antoni Siewińki, in chapter 2). As I understand him, Bartov attributes antisemitism mainly to the rival nationalisms between Poles and Ukrainians; Jews were harassed and attacked in order to prevent them from helping the nationalistic rival. Racist talk was not uncommon (by the way, I wonder whether it was typical of Jews, too; for example, did they call the Ukrainians khokbly?), but charges of economic treachery prevailed. In a word, local nationalism seemed to be a version of modern antisemitism, in which mundane arguments were more common than religious ones.

Bartov, probably correctly, argues that the First World War and the civil wars of 1918 to I 920 left Buczacz Jews in great poverty, and that the 1929 Great Depression merely worsened the situation. However, in chapter 3 Bartov does not focus on Jewish misery, but describes the Polish oppression of the Ukrainians, who during the Great War and the civil wars hankered after an independent Ukraine, and afterwards, particularly in the I930s, were suppressed by the Polish government for their alleged and real separation policy.

The reason to single out the Ukrainian hardships is evidently that it may partly explain why especially the most extreme nationalists turned to collaborators. An additional explanation proposed by the book is the memory of the Soviet rule from late 1939 to June I94 I, stressing such things as seizures of property, total transformation of economic and political life accompanied by swift changes in administration, or deportations to the Soviet North or Siberia, and attributing them, in the Ukrainian case at least, to the 'Jewish Bolsheviks'. Events of the r 93os and the first Soviet period are used as explanations for local collaboration in the Baltic States, too.

Bartov also points out the psychological dimension; Ukrainians felt themselves victims of both Polish and Bolshevik tyranny, and because for various reasons they were convinced that behind these tyrants lurked the Jew they became 'willing henchmen' in the German eradication of the Jews. Needless to say, Polish and Jewish memories also emphasised their being victims, not tyrants.

Chapter 5 presents the Holocaust in Buczacz in practice. We hear (through voices of survivors and other people) accounts of mass shootings of the Jews; as in the Baltic States, here, too, only a minority of local Jews were sent to extermination camps. Bartov criticises Ukrainians for serving the Nazis as auxiliary police, but does not spare the Jewish organisations (Judenrat and Ordnungsdienst or the Jewish Police) either. In the manner of Hannah Arendt, he castigates the Judenrat's and the Jewish Policy leaders for servility and cruelty. Unlike Arendt, he also quotes some survivors to the effect that the Buczacz Judenrat was better than many others. I think that his ambivalence is correct; no nation en masse is entirely good or evil, but a mixture of both.

According to its title, Chapter 6 discusses daily life during the genocide. 'Daily life' here means two things, first, how some, particularly children, were saved by benevolent people, of which several seemed to be Poles, and not a few Catholic nuns or priests, and, second, how 
intimidation and violence become a 'normal' part of everyday life; you never could tell what horrors would happen next. In other words, daily life was a combination of hope and terror.

During the late I 940s, the former Polish territory was annexed to the Soviet Ukraine and the population exchanges between Poland and the Soviet Union changed the formerly multiethnic territory into an almost homogeneous Ukrainian land. (Of course, later Soviet policy brought a lot of Russians here, but that is another story.) Jewish monuments and memories of the Jews were either destroyed or transformed to fit the Soviet narrative on the Great Patriotic War, in which all nations unanimously fought the Nazi enemy and all 'casualties' were 'Soviet citizens', not, for example, Jews or Ukrainians.

This obfuscation of the Jewish past and Jewish people evidently continues today. In the Aftermath, Bartov quotes a former extreme nationalist Ukrainian fighter, who (in 2005) insisted that the killing of the Jews in the Holocaust was a purely German action. It seems that, in the same manner as some people in the Baltic countries, this man, seeing himself and his nation as victims of the Soviet rule, wants to emphasise his and his nation's victimhood and keep quiet about their role in contributing to the other people's suffering.

I much appreciate Bartov's decision to put local events in perspective, and not focus narrowly on the few years of the early I 940 o but to see local events as evolving from previous historical events. While this may at places seem too mechanical, and while Bartov may focus too one-sidedly on Jewish suffering in history (I'm sure that Jewish life also contained some brighter moments), I find it extremely important not to forget that the present has a past (or, rather, pasts), which all too often is abused to legitimate present claims; for, in the end, what is antisemitism if not a barrage of selected historical arguments?

Bartov's compositional strategy is conscious, recurrent quotation from archival sources (diaries, official reports and other documents, examination records, etc.). These 'human voices' make the narrative more vivid than mere summaries of texts, or a 'pure' analysis, although Bartov could be rebuked for allowing little space for female voices. Or is it just that Buczacz survivors were predominantly men?

On the other hand, Bartov's variety of history-telling presupposes in the reader some familiarity with the developments of the Holocaust in Eastern Europe in its early stage, that is, before the 'heydays' of the extermination camps of Auschwitz type, when more than one million Jews were shot dead in the Baltic States, Belarus and Ukraine. Comparison of the events in Buczacz with the Baltic States and Belarus reveals a general pattern in the genocide carried out during the Second World War, but also points out that, because history is made by people, not by patterns, there are important differences in 'similarity'.

Taken as a whole, this book is 'an exemplary microhistory' - not only of the Holocaust, as Saul Friedlander states, but Galician Jewishgentile encounters and the ways they are perceived, remembered and recycled in particular contexts by various individuals.

\section{TEUVO LAITILA}

Teuvo Laitila has taken his PhD in Cultural Anthropology in Helsinki University. He is also university lecturer in Comparative Religion. Currently he teaches Comparative Religion and Orthodox Church History at the University of Eastern Finland. He has published books and articles (most of them in Finnish) on Orthodox Christianity, Islam and popular religion in Finland, Karelia, Russia, Ukraine and the Balkans, and the history of Jews in Finland before the Second World War. His current research concentrates on Jewish-gentile relations in the Baltic and Ukraine. 